\title{
Ramazan Dikmen'in Hikâyeleri ve Modern Dünyanın Öğütücülüğüne itiraz
}

\author{
Şükrü Can BALTA*
}

\begin{abstract}
ÖZ
Yaşamın temel eğilimlerinden biri, insanın kendini, muhitini ve yerküreyi anlamlandırma girişimidir. Bazı zümreler ise tanıyı koymakla yetinmeyerek kendi bulgularını kamuyla veya okurla paylaşmayı tercih eder. Bu bağlamda her özgün görüş, hali hazırdaki tezlere antitez olma potansiyeli taşımaktadır. Moderniteye muhalif bir çizgide ve eleştirel yaklaşımlarla hikâye kaleme alan Ramazan Dikmen, geleneksel doktrinlerden ve kadim bilinçten yana bir yaklaşım içindedir. $\mathrm{O}$, ülke ve dünya ölçeğinde yaşanmakta olan medeniyet krizini tüm çıplaklığıyla metinlerine yansıtmaya gayret ederken sahip olduğu duygu yüklü söylemle bireyin salt rasyonel akılla ve faydacı tavırla yaratıllı̧ melekelerinden yoksun kalacağını düşünmektedir. Akıl, ancak sezgi, bilinç, hassasiyet ve merhametle insan yaşamına değer katabilir. Aksi takdirde modernizm ve sermaye, çağdaş insanı alenen tehdit eden bir urdan farksızdır. Dolayısıyla tahakkuk etmekte olan zamanın kötücül ve netameli ruhuna getirilecek itiraz, kaçınılmaz olacaktır. Ramazan Dikmen'in hikâyeleri bu yönüyle birer hesaplaşma metnidir. Bu hesaplaşmalar bireyselliğe de toplumsallığa da açıktır. Dikmen, ihtiyaca göre ironik üsluba başvurabildiği gibi dolaysız anlatma ve gösterme becerilerinden de yararlanmıştır. Kahramanların hatrı sayılır bir miktarı isimsizdir. Nitekim kimlik ve duruş, isimden önce gelir. Yazar, farklı yapısal denemelerde ve teşebbüslerde bulunur. Bilindik, standart ölçülerin yanında yeni ve alternatif biçim modelleri sunar. Ramazan Dikmen'in hikâyelerinde yüklü miktarda ve çaresiz bir karamsarlık
\end{abstract}

Arş. Gör., Karamanoğlu Mehmetbey Üniversitesi Edebiyat Fakültesi Türk Dili ve Edebiyatı Bölümü Karaman /Türkiye

E-posta: sukrucanbalta@gmail.com, ORCID: 0000-0002-3987-3090,DOI: 10.32704/erdem.749069 Makale Gönderim Tarihi: 03.10.2019 * Makale Kabul Tarihi: 15.04.2020 * (S. ve Edebiyat Mk.) 
hâli olmadığı gibi romantik olgularla bezeli bir dünya tasavvuru da mevcut değildir. İnsanoğlu ve yeryüzü, farklı kanallarla mütemadiyen istila halindedir. Çekilen ve çekilmekte olan acı ve sstıraplar ötelenir fakat unutturulmaz, bilhassa hatırlatılır. Bu doğrultuda kişiye dayanak olan insani normlar devreye girer. Yanyana ve temas halindeki iki insan birbirini çürütebildiği gibi diriltebilir de. Dostlukları inşa eden husus, mezkûr dirilişler ve çıkarsız etkileşim halleridir. Yapıcı ve sslah edici müşterek temenniler, Ramazan Dikmen'in hikâyelerindeki olay örgüsüne yön verir. Ramazan Dikmen'e göre performans toplumu, kanaatin geri planda kalmasina zemin hazırlar. İlaveten kargaşa ve kaos ânında insanı teskin eden, özel uğraş ve ihtimamla müşahhas bir karaktere bürünen "yuva"ların apartlara evrimi kaygı verici boyutlardadır. Ancak yeryüzündeki ideal ve ilkeli tiplemelerin varllğ̆1, eşya ve mekânın yitirilmesine set çekecektir.

Bu çalı̧̧a, Ramazan Dikmen'in hikâyelerindeki insani ve kültürel yozlaşmanın farklı boyutlarına değinmeyi hedeflemektedir. Ayrıca kolektif hafızanın unutma tehlikesi yaşadığı, kuşatıcı niteliğiyle daima evrenselleşme temayülü gösteren ulvi değerler de irdelenecektir.

Anahtar Kelimeler: Ramazan Dikmen, hikâye, modernizm, bilinç, hafiza, itiraz. 


\title{
Ramazan Dikmen's Stories and an Objection to Modern World's Grinding
}

\begin{abstract}
One of lifes's basic tendencies is, that man explains himself the meaning of his being, his neighborhood and the meaning of the globe. Somebody are not content with just making diagnosis and so they prefer to share their results with the public and the reader. In this context, every unique opinion has a potential for being an antithesis to present thesises. Ramazan Dikmen, who indites stories with a critical approach against the modernity, shows an attitude for traditional doctrine and ancient awareness up. He tries starkly to reflect in his textes the civilization's crises, which happened on the country's and world's scale. With his emotional way of expression, he thinks that a person, just concentrated on rational mind and pragmatism, will be lack of the resons for his existence. Mind can just enrich a man's life with intuition, consciousness, sensibility and mercy. Otherwise modernity and capital are alike a tumor, threating apparently the modern man. So, it will become unavoidable to object for the malicious and ominous ghost of the time, which is realizable. On that sense, Ramazan Dikmen's stories are textes of clearance. This clearances are on individualism and collectivism. If it's necessary, Dikmen applies on ironic tongue and benefits on explicitations and direct showing abilities. A remarkable amount of the characters are nameless. Thus, identity and attitude comes before name. The author tries different structural enterprises. Beside the known, standart measures he offers alternative styles. In Ramazan Dikmen's stories does the substantial amount and desperate pessimistic mood not exist; as like as an imagination of the world notated with romantic facts is unavailable. Humanity and earth are always in temper of occupation. The suffering and pain are deferred but aren't caused to forget, they are especially reminded. According to that, humane norms, which are like the ground to a person, step in. Two person, which are side-by-side and in contact, can demolish but also resurrect each other. The aspect, that builds friendships, is aforesaid resurrect and interaction without profitless. The requests, which are constructive and reformatory, are collimating for the plot in Ramazan Dikmen's stories. In Ramazan Dikmen's opinion, the society of performance sets ground for the satisfaction's recede into the background. Farhter is the evolution of "homes" with a nice and concrete character, that calm any person in case of any chaos, into "aparts" is worrisome. But the existence of ideal and principled typing on the earth can barricade losts of wares and places.
\end{abstract}

This work aimes to mention the different aspects of humanitarian and cultural devolution in Ramazan Dikmen's stories. Also divine values, always tended with their encircling quality to become universal, which are under the threat for oblivion by the collective memory, are studied.

Keywords: Ramazan Dikmen, story, modernity, consciousness, memory, objection. 


\section{Giriş}

1956 y1lında Balıkesir/Dursunbey'de dünyaya gelen Ramazan Dikmen, 1 Türk edebiyatının, en velud dönemindeyken, erken yaşta hayatını kaybetmiş (1977) sanatçılarındandır. Hikâye, günlük, deneme ve çeviri türünde yazılar neşreden Dikmen, hikâyeci kimliğiyle ön plandadır. İlk hikâyesi, 1974 yılında Akşam gazetesinde yayımlanmıştır. İki hikâye kitabından biri olan Kıyıya Vuranlar 1996, Afife Ablanın Incileri ise 1997 y1lında basılmıştır. Bu hikâyeler, 2006 yılında, Hece Yayınları tarafindan Mubayyer (Bütün Öyküler) adı altında tek bir kitapta okura sunulmuştur.

Yazma hususunda derin bir hassasiyet taşıyan Ramazan Dikmen, aşırı özeni nedeniyle yazılarını seyrek yayımlamayı tercih etmiştir (Lekesiz 2017: 157). Yazma eyleminin disiplin gerektiren bir işçilik ürünü olduğunu düşünse de, hikâyelerinin çoğu zaman, irticalen teşekkül ettiğini vurgulamadan geçmez:

"Benim hikâyelerim, bir anlamda kendi kendini yazan hikâyelerdir. Önceden ölçülüp biçilen bir şekilde kurgulanmış, planlanmış hikâyeler değildir. Dolayısıyla daha önceden belli olmayan, ama yazarak ulaşılan bir macerayı içerir.” (Dikmen 2016: 75)

Dikmen'e göre hikâyelere hayat veren etmenler, herhangi bir görüntünün veya küçük bir olayın hikâyecide açığa çıkaracağı bir kıvılcımdan ibaret olabilmektedir. Hikâyelerine oturmuş genel niteliklerden biri, yapısal olarak kısa cümle düzenini tercih etmesidir. Hâlihazırdaki bu tür kısa cümleler, metne iç ahenk katarken olay örgüsünün akıcı bir suretle seyretmesine imkân tanır. Sanatçının hikâyelerine sinen genel bir husus da, tematik başlık farklılık arz etse de üzerinde 1srarcı olduğu zarif üslubudur. Fakat üslubundaki zarafet, olay örgüsündeki kavgacılığı ve gür sesliliği de bastırmamaktadır. "Bunun yanında belki en önemli yön, yaşanan iç gelişme, ruhi seyirdir. Sanki hikâyecinin yaşadığı bir sülûk söz konusudur” (Kahraman, 1997: 36).

Ramazan Dikmen, Kayıtlar dergisinin Kasım 1992 tarihli 25.sayısında hikâye üzerine taşıdığ 1 görüşlerine yer vermiş̧tir. Ona göre sanatsal işlevi bakımından iki tür hikâye vardır:

1-) Yalnız sanat için, sanatın isterlerini daima önde tutarak yazılmış hikâye.

2-) Yazarının düşüncelerine tercüman olma işlevi üstlenmiş, bu yönde mesaj vermeye adanmış, tezli hikâye. 
Hikâye gibi tahkiyeli metinlerle rapor ya da röportaj arasındaki en büyük fark, "insan" unsurunun göz ardı edilmeyerek mümkün olduğunca yakın plana inilmesidir. Dolayısıyla hikâyede kişilere ve çevrelerine daha yakından bakılır. Bunun için tasvirler yapılır, portreler çizilir, ayrıntılara, olaylar arasında sebep sonuç ilişkilerine inilir. Sonra kişilerin iç dünyalarına girilir, onların düşünceleri, hayalleri, sevinçleri, öfkeleri, heyecanları anlatılır (Dikmen 2016: 63). Dikmen, hikâyede zihinsel bir işleyiş olduğunu ve bu işleyişin tamamlanmış yekpareliği inşa ettiğini düşünmektedir.

Sanatçı, orta sınıfin başından geçen bir gününü, tüm sadeliğiyle betimlemeye gayret eder. Durakta otobüs bekleyen, sonu gelmeyen taksitlerden bunalan, saygin bir hüzün sahibi, seviyeli ve platonik aşka gark olmuş insan tiplerine Dikmen, hikâyelerinde yer verir. Bunlar haricinde, idealize ettiği tiplemeler de mevcuttur. Örneğin “Sır” hikâyesinde, kişiler arasında geçen konuşmada bir ilkokul öğretmeninin şu sözleri, taşıdığı mesleğin kutsiyetini göstermesi bakımından önemlidir:

"Evet, zor olmasına zor tabi. Ama ben çok seviyorum. Şerefli, kutsal bir meslek. Gerçi parası az ama. Çünkü bugünün küçükleri, yarının büyükleri demişler. Geleceğin doktorlarına, mühendislerine, devlet adamlarına bugünden hizmet etmek, onların yetişmesine katkıda bulunmak, hani manevi bakımdan büyük bir mutluluk veriyor insana." (Dikmen 2015: 100)

Dikmen'in, bu tür tiplemeleri nicelik olarak vasat bir haldedir. Fakat hikâyelerindeki en kavi unsurlardan biri, okurun, değerini her dönem muhafaza edecek olan ideal, kaliteli insan tiplerinin var olacağına dair kanaat taşımasıdır. Bu insan tasavvuru, mekanik öğelerle çevrelenmiş, cihazların, ideolojilerin yahut dogmatik oluşumların tahakkümü altında olanların aksine; hür, vicdan sahibi ve hikmetli kişilerdir. Sanatçının hikâyelerinde Anadolu ruhunu yansıtan simge ve değerlerin yer almasının yanı sıra dönemin buluşma mekânı olarak pastaneler özellikle tercih edilir. Dahası anlatıcı ve kahramanlar nazarında olumlu çağrışımlar yapan, günümüzde belirli bir sınıfa yahut sosyal tabakaya mahsus olmaktan sıyrılıp genişleyen çay ve çayevleri de nadir refiklerdendir.

Mazi ve anı, Ramazan Dikmen için anahtar sözcükler olsa da yazar, gündemin ve sosyal hayatın sıkı takipçisidir. Nitekim yayımlanmış hikâyelerin yazılma tarihleri 1979 ila 1996 yılları arasını kapsamaktadır. Bu on yedi yıllik süre zarfinda, Türkiye ve dünya ölçeğinde meydana gelen ve Dikmen’in hikâyelerinde üzerinde defaatle durduğu, dikkat çektiği, sorguladığı ve eleştirdiği siyasi infial ve olaylar kabaca şu şekildedir: 


\begin{tabular}{|c|c|c|c|}
\hline Tarih & Olay & Hikâyedeki Yansıması & Hikâye Adı ve Tarihi \\
\hline 1978 & İran Devrimi & Durum Değerlendirmesi & “Sonrası” (1982) \\
\hline 1979 & $\begin{array}{l}\text { Sovyet Rusya'nın } \\
\text { Afganistan'ı İşgali }\end{array}$ & İşgal Protestosu & “Yavuz" (1980) \\
\hline 1980 & 12 Eylül Darbesi & $\begin{array}{l}\text { Öğrenci Çatışmaları ve } \\
\text { Sokağa Çıkma Yasağı }\end{array}$ & $\begin{array}{c}\text { "Kartpostal” (1979) } \\
\text { "Bir Akşam İçin Ön } \\
\text { Çalışma” (1981) }\end{array}$ \\
\hline 1980 & İran-Irak Savaşı & Durum Değerlendirmesi & “Sonrası” (1982) \\
\hline
\end{tabular}

'İroni, Ramazan Dikmen hikâyelerinde mühim bir meseledir. Ramazan Dikmen'in hemen her hikâyesinde ironi bir şekilde yer alır ancak "Yavuz" (1980), "Defter”(1990), “Ödül Töreni” (1991) hikâyelerinde ironi, hikâyelerin adeta öznesi kılınmıştır” (Lekesiz, 2017: 158). Dikmen’in kahramanları, ekseriyetle özel bir isim de taşımaz. Bu durum, yazarın bilinçli bir tercihi değildir. Nitekim yazarın ifadesiyle aslolan, kahramanların namını öne çıkarmaktan öte; onların iç dünyalarına inebilme ayrıcalığını taşımaktır (Dikmen 2016: 76). Mevzubahis hikâyelerdeki sözcük dizini ise oldukça karakteristik bir yapıdadır. Yazarın kurguya dair gösterdiği ihtimam, sözcük ve fiil seçimine de intikal eder. Bu ifade biçimleri, dolaşımda olanların yanı sıra ekstrem isim, sıfat ve filllerden meydana gelmektedir. "Avurt, yeğni, esrik, kunt, süreğen, işmar etmek, kaykılmak, sembiyoz, yaşmaklı, partal, izbe, şıvgın, uçkun, tavsımak, ırgalanmak" benzeri çarpıcı ifadeler, akla ilk gelenlerdir.

Gelenek, Ramazan Dikmen’in hikâyelerindeki izlekler üzerinde ana etmendir. Entelektüel düzlemde bin yıllık bir birikime sahip Türk-İslam geleneği, çağdaşı olduğu cemiyetin muayyen kesimleri tarafından göz ardı edilen bir unsur olarak görülse de yazar için hâlen işlek bir kaynaktır. Haliyle hikâyelerindeki aşk, hüzün, yalnızlık ve ayrılık izleklerinin temel dayanağı, bu "ana çizgi"dir. "Peygamber sevgisi, platonik sevda, fena duygusu, hamd, şükür, tevekkül, ebedi hayata mutlu bir doğuş olarak inanılan ölüm, aşk sarhoşluğu, hüzün, hasret, gurbet ve çile, ele alış biçimleri çağdan çağa farklılık arz etse de değişmeyen izleklerdir” (Dikmen 2016: 14). Bu bağlamda inanç unsuru da yazar için mühim bir meseledir. "Günah" hikâyesinde, bunaltı yaşayan başkişi (ben anlatıcı) ile yakın dostu Vedat arasında geçen konuşmada, nasihat ve inanç içerikli cümleler bulunmaktadır: 
- Sorma Vedaţ̧ı̆̆ım, bugünler çok bunaliyorum.

- Kardeşim, inanan insan nasıl bunalır, doğrusu bunu pek anlayamıyorum. (s.125)

"Ağlama Güncesi” hikâyesinde ise yazar için ünlemli bir mesele olan inanç unsuru, sarfedilen sözlerle adeta bir manifesto niteliği taşımaktadır:

“...adı ne olursa olsun batıl bir yaşama biçiminin ürünleriyle beslenmeye çalı̧mak, yalnızca yaralarımızı azdırıyor bizim...Acılarımız yön verecek umutlarımıza...Yıkılacağız, yıkılacağız ki ayağımız suya ersin, salt güvenin, salt umudun yalnız Allah'a olduğunu anlayabilelim.”(s.131-132)

"Geçende", "Yavuz", "Muhayyer" hikâyelerinde ve sair metinlerin çoğunda doğrudan İslam’la bağdaşan ülkü değer ve simgelerin varlığından bahsetmek de mümkündür.

\section{Müzik ve Seslerin Simgesel Varlığı}

"Çok insan anliyamaz eski mûsikîmizden Ve ondan anlamiyan bir şey anlamaz bizden."

Yahya Kemal

Musiki, insan ruhunun derin hislerini alelade dilden daha iyi anlatır. Onda ulvi âlemlere yükselten bir kudret vardır (Kaplan 2012: 208). Nağme içeren bu kudret, Ramazan Dikmen hikâyelerinde bir hayli faaldir. Müziğe, yakın bir alaka besleyen yazar, müzik terimlerine, müzik makamlarına ve radyo fasıllarına bizatihi değinir. Müzik türleri içinde klasik Türk musikisinin özel bir yeri vardır. Nitekim Hüseyni makamının inici biçimi olan ve Arapçada "beğeniye bırakılmış, serbest” (Teymur 2010: 80) anlamındaki Muhayyer, Dikmen’in hikâye isimlerinden birine kaynaklık etmesinin yanı sıra toplu hikâye kitab1nın da adıdır. Toplu hikâye kitabının ilk hikâyesi olan "Muhayyer"de, musiki unsurları, olay örgüsünün bir nevi ilham kaynağıdır. 1990 yılında Kayıtlar dergisinde yayımlanan bu hikâyenin giriş cümlesi, doğrudan Türk musikisi makamlarına ilişkindir: "Artık radyoda fasıllar çalmıyor. Ne mubayyer, ne hicaz, ne uşsak" (s.9). Tasavvuf öğretileriyle, utanmanın erdemiyle, aile mefhumuyla, müzik üzerinden sarfedilen hayıllanma ve şikâyet güdüsüyle destekli söz konusu hikâye, hususi bir isim taşımayan ve "müftü kızı" sıfatıyla tanıtılan genç bir kadının etrafında şekillenir. Özel ilgi ve yeteneğinin etkisiyle lise yıllarında cemiyet korosuna iştirak eden genç kadının müzikle olan iştigali, hikâye boyunca devam eder. Olay örgüsünün ikinci bölümü, yıllar sonrasına 
uzanır. Birtakım ihtiraslarından dolayı kendisi gibi musikişinas ve solist olan Turan'la ortak bir yaşam kuramayan karakter, kütüphanenin issızlığına ve münzeviliğine sığınırken müzik enstrümanlarıyla da depreşen ruhunu telkin etme uğraşındadır. İkinci ve son bölümde söz, ben anlatıcıya evrilir. Gözlemi yapan, hikâyenin odağındaki kadının evine misafır olan birinci tekil şahsın kendisidir:

"Fotoğrafin solunda büyükçe bir ud ve kemençe asıl1. Yemekten sonra beni kırmıyor. Udu duvardan indiriyor. Mızrapla bir süre gelişigüzel vuruyor tellere. Sonra çalmaya başlıyor. İnce, içten bir segâh. Evet. Bende kalan görüntülerinden biri daha. Kucağında udu, başı yana eğik. Gözleri kapalı. Tellerin üstünde donmuş eli, sonsuz bir taksimde geziniyor" (s.25).

Müziğin, durağanlığı coşkunluğa eriştiren bir mekanizma olmasının yanı sıra Ramazan Dikmen nazarında Türk müziğinin çağrıştırıcı özelliği de vardır. Ayrıca musiki, henüz yazmaya başlamadan önce hikâyeye yerleştireceği epizotları kendine ilham etmektedir (Dikmen 2016: 77). Yazar, "Muhayyer"i kaleme alırken yurtdışında bulunmasından ötürü çektiği Anadolu ve musiki hasretini radyodan dinledikleri Türk müzikleriyle yatıştırmaya çalıştı̆̆ını da ilave eder. Dikmen'in "Muhayyer"de geçen "Eski şarkılar belli ki onu uzak hatıralara yolluyordu" (s.26) cümlesi, bir nevi söz konusu sabitenin edebi düzlemdeki ispatı ve tanı̆̆ıdır.

Radyo, sosyolojik açıdan ve insan psikolojisi açısından gurbetle daima bağdaşan bir cihaz olarak telakki edilir. Günümüz dünyasında televizyon ve bilhassa internet, kitle iletişim hususunda nüfuz sahibi olsa da bu iki gücün, radyonun etki ve yayılımcılığını tam anlamıyla bastıramadığı görülür. Bu haliyle radyo halen, şehirdeki ve taşradaki insanın ses dalgalarından müteşekkil ulağ1 konumundadır. Ramazan Dikmen hikâyelerinde açar simgelerin başında gelen radyo, çoğu hikâyede kendine yer bulur. İşlevselliği itibariyle bu mükerrer simgede vatan hasreti, modernizme karşı gösterilen bilinçli mukavemet ve merak unsuru benzeri duygular mevcuttur. İlaveten olay örgüsü içinde durum değerlendirmesi ve tasvir yapılmasına imkân tanıyan simgelerden biri radyodur. Aşağıdaki tablo, sanatçının toplu hikâyelerinde tekrar eden bu cihazın simgesel döngüsünü temsil etmektedir: 


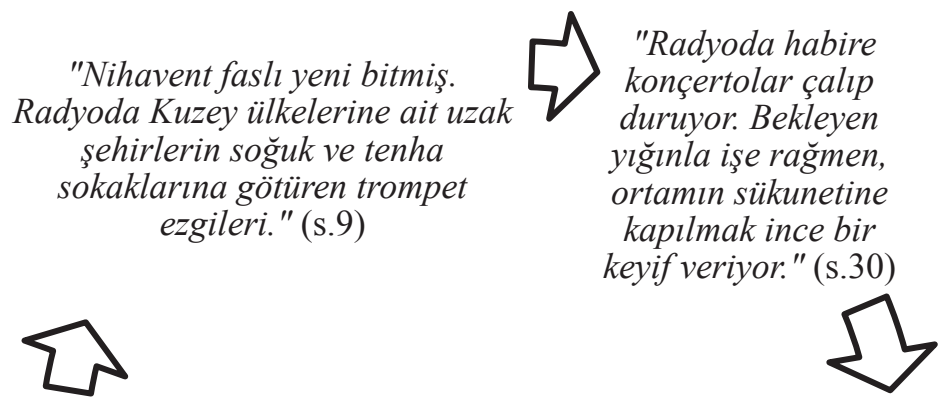

"Komşu odadaki radyo susmuyor: 'Saat on. Burasi te-re-te Istanbul radyosu. Sayın dinleyiciler'." (s.134)

"Radyoda gürül gürül bir koro: candan bir dostla derin sohbetlere dalmaya ya da yıllardır özlemi çekilen, uzaklardaki ruhdaşa sayfalar dolusu yazmaya çă̆ıran o eski şarkılar." (s46)
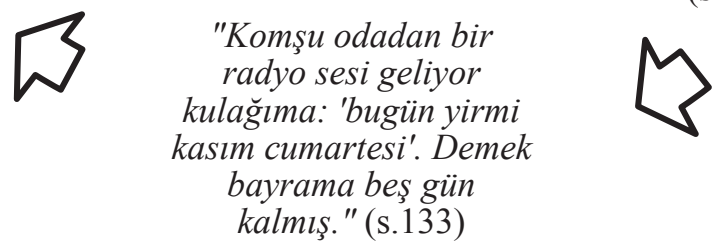

“Sen Değil Ayak Seslerin”, bütünüyle ses unsurlarılla donatılan bir hikâyedir. Metnin olağan akışı dışında belirli kısımlara yerleştirilen, kendi içinde müstakil ve bağımsız bir bütünlük arz eden bölümler, Dikmen’in bilinçli ve 1srarla denediği yapısal anlamdaki farklılıklardan kaynaklanmaktadır. Bu hikâyede de özel isim taşımayan şahıslar bulunur. Olaylar, ben anlatıcının diliyle okura sunulur. Ben anlatıcı, yazarın aktardığı sınırlı bilgilerden yola çıkıldığında, gününün büyük çoğunluğunu dosyalar arasında geçiren, alış1lagelmiş bir iş hayatına sahip, klasik memur tiplemesidir. Fakat meseleye özgünlük katan husus, bu tiplemenin salt ayak seslerinden (ki metindeki yansıma ifadesi taktak’lardır) yola çıkarak zihninde kurguladığı tasvirlerdir:

"Tak tak tak. Lakin ne de kısacık sürüyorlar. Kulaklarıma dolmalarıyla, çekilip gitmeleri bir oluyor. İnsanın doyamadığı ama yine de uyanmaktan kurtulamadığı bir rüyanın sonları gibi. Sert ökçelerin mozaik zeminle temasından çıkan son sesler, derin bir suda gibi yiterken, uçkun mısralar geçiyor zihnimden” (s.30). 
Tipleme, etkisi altında kaldığı sesleri duyumsayarak her firsatta gizemli bir kadın profili tasavvur eder. Bu tasavvurda ideal olan ve beklenilen nitelikleri taşıması öngörülen insan düşlenmektedir:

"Uzun bir boy yokluyor hayalimi. Uzun boy ve siyah saçlar. Sonra beyaz ten. İri, kıvılcım karası gözler. Sesler yaklaştıkça o da yaklaşıyor. Bense artık biliyorum: Günde kaç kez boğuk yankıları koridoru dolduran ve onca gürültü içinde kulaklarımın yakalamakta usta kesildiği tak-taklar bir gün eşiğimin önünde ansızın duracak. Kemik rengi kapıdan kuş gagalarından çıkma vuruşlara benzer tık-tıklar gelecek. Reze yavaş yavaş oynayacak. Kapı usulcuk aralanacak"(s.32).

Gerçek ve düş arasındaki bu tasavvur, metin boyunca muğlâk kalsa da çelişkili ifadeler, sürükleyiciliği de temin eder. "Oysa ne ayak seslerini duydum ne kapının vurulduğunu" (s.32) ile "Belki de bunlar olmayacak. Hiç olmayacak. Yalnız bana öyle gelecek. Çünkü aslında onlar galiba yoktular. Hiç yoktular" (s.35) şeklindeki cümleler, ses unsurlarının kaynaklık ettiği, yazarın ifadesiyle "düşsel bir silüet" (s.31) olarak değerlendirilmesine sebebiyet vermektedir. Yine de, dış dünyada meydana gelen seslerin iç dünyadaki sesleri harekete geçirmesi, üzerinde durulması gereken bir bahistir.

\section{İnsanı İnsana Pekiştiren Kardeşlik ve Dostluk Hukuku}

"Ve anliyorum ki bir dosta özlem duymak, bir dost özlemine bahçıvan olmak, böylesine güzelmiş demek...”

Ramazan Dikmen

21. yüzyıl dünyasında teknolojik terakkinin olabildiğince bir ivmeyle beşeriyeti etkisi altına alması, yerkürenin muhtelif bölgelerinde yaşayan, coğrafya ve tarihi hadiselerin etkisiyle sahip olunan milli kültürlerin, birbiri içinde kaynaşmasına, dolayısıyla küresel bir etkileşimin meydana gelmesine zemin hazırlar. Fakat insan, bir cihetle uzak iklimdeki ırkdaşlarını keşfedip tanırken, diğer cihetle yanı başındaki kadim bağları göz ardı etmeye başlar. Dolayısıyla salt Türk kültüründe değil, dünya genelindeki insani ilişkiler düzleminde daima önem taşıyan kardeşlik ve dostluk bağı, bilhassa içinde bulunulan çağda zarar görmektedir. Bu kırılmanın sebepleri arasında samimiyet yoksunluğu, menfaatperestlik, insanın muhatabına karşı duyduğu tahammülsüzlük ve güç mücadelesi gibi unsurlar gösterilebilir. 
İnsani ilişkiler bağlamında dostluk ve kardeşlik hukuku, kolektif bir ihtiyaçtır. Maslow, bireyin ihtiyaçlarını hiyerarşik bir düzende şematize ettiği tablosunda, insanın temel güdülerinden olan sosyalleşmeye (sevgi ve ait olma basamağı), fizyolojik ve güvenlik ihtiyaçların akabinde yer verir. Dostluğa dair estetik bir bakış açısı geliştiren Fethi Gemuhluoğlu ise meselenin özünü, hadisten mülhem bir ifadeyle "Önce yoldaş, sonra yol" (Gemuhluoğlu 2016: 25) biçiminde tanımlar ve "Her şey gönülde cereyan ediyor." (Gemuhluoğlu 2016: 26) cümlesiyle de özetler. Tanımlamalar ve yaklaşımlar, müktesebata göre farklılık gösterse de genel kanaat, doğru insanın, hayat denilen girift ve muammalı yolda, yoldaşına dayanak olmasıdır.

Kafkaesk bir üslupla giriş yapılan "Susan Adamın Hikâyesi”, varoluşsal bir sancı çerçevesinde kaleme alınır. Mana arayışındaki, Zekeriyavari susuşlar sahibi Ramiz'in dostu İhsan'la olan münasebeti, Dikmen'in dostluğa dair taşıdığ kanaati saptamak için önemli bir metindir. Geriye dönüş tekniğinin de kullanıldığı bu hikâyede İ̀san, Ramiz’in manevi ihtiyaçlarından (inanç) doğan, özerk yapıdaki yalnızlık alanına tam anlamıyla yaklaştırılmasa da iki dost arasındaki naif tutum hikâye boyunca, ardış1k bir biçimde kardeşlikdostluk ilkesini pekiştiren cümleler içinde birbirini izler. Aşağıdaki örnekler, pekiştireç cümlelerinin $(\mathrm{PC})$ bir araya getirilmiş halidir:

PC-1: "Bebekliklerinden beri arkadaşt1lar." (s.45)

PC-2: “İlkokulda bir sınıfa düştüler, beş yıl aynı sırada oturdular.” (s.45)

PC-3: "Herkes onları birbirine kardeş gibi yakın gördü.” (s.45)

PC-4: “Sıcak yaz öğlenleri ıslıklar çalarak Sazlık deresine koştular." (s.44)

PC-5: “Lise yıllarıysa bu yakınlığı daha da kökleştirdi.” (s.45)

PC-6: "Birlikte ilk gençlik acılarını tattılar, ilk sevdalarına birlikte tutuldular." (s.45)

PC-7: "(İş hayatına atıldıklarında) Yine bütün şehir uykudayken uzun gece yürüyüşlerine çıtıtılar.” (s.45)

PC-8: "Kışlarıysa sürekli yazışmayı unutmadılar.” (s.45)

Benzer bir durum, “Günah”ta da bulunur. "Günah”, sorgulama ve pişmanlık duygularının tesiriyle iç konuşma tekniğinin hâkim olduğu bir iç hesaplaşma metnidir. Ben anlatıcı olan başkişinin yaşadığı sancıma karşısında yazarın vurgusuyla "dostluktan öte" (s.124) bir ilgiyle dostuna arka çıan Vedat'ın şu iki tanık cümlesi, duyarlılığ1 resmetmektedir: 
"Orasını bilmem ama, biz birbirimizden sorumluyuz." (s.124)

"Ne demek beni ilgilendirmez. Belki herkesten çok beni ilgilendirir. Biz kardeşiz, anladın mı, kardeş." (s.124)

Vedat'ın sergilediği her insani refleks, Nurettin Topçu'nun ifadesiyle "pek az rastlanan yüksek ve müstesna ruh hallerine" mahsustur ve aynı zamanda "insan şahsiyetinin en yukarı basamaklarında rastlanabilecek" (Topçu 2019: 80) niteliktedir. Başkişi, dostu Vedat'a hitaben "Kardeşliğimizle eritirdik yüreklerimizdeki donları" sözü, hâlihazırdaki bu kutsal dayanı̧̧manın kesifleşen boyutunu ortaya koymaktadır. Kalabalıklar içerisinde geçmesine rağmen temelde yalnızlık üzerine inşa edilen "Yakın" hikâyesinde de diğer örneklere benzer bir biçimde kahramanlar, isim taşımayan başkişi ve isim sahibi diğerleri olmak üzere iki zümreye ayrılır. Ayrıca Dikmen’in çoğu metninde olduğu gibi bu metinde de zaman akışı olağan seyrinde ilerlemez. Tren yolculuğu sırasında yapılan tasvirlerle ve birtakım leitmotivlerle bezeli "Yakın" hikâyesinde, diğer kişilere nazaran Cüneyt, anlatıcı gözünde seçkin telakki edilir. Nitekim Cüneyt' in trafik kazasında kaybedilmiş olması, onun hakkındaki varsayımların müessir ve buruk bir üslup aracılı̆̆ıyla aktarılmasına sebebiyet verir:

"O gün, trenin kaç saat gecikmesine rağmen bikmadan garda beni bekleyen Cüneyt. Onun her zamanki inceliği, özverisi, dost gözetir hâli...Kalkıp ona gideceğiz. Gece yarılarına değin söyleşeceğiz. Eski günlerden konuşacağız: aşklardan, sevdalardan, umutlardan, gülmemiş hayallerden, yenilgilerden, yıkımlardan. Son şiirlerini okuyacak bana. Son plaklarını dinletecek.” (s.203)

Bu minvalde Ramazan Dikmen’in mektuplarındaki biçim ve içerik de kökten farklı değildir. Yazar, özdeş duygudan, coşkudan ve dostluk üzerindeki ısrarcı duruşundan ödün vermeyerek (yayımlanmış) mektuplarına "sevgili kardeşim, aziz dostum, sevgili gönüldaşım” benzeri hitaplarla başlar. Bu, Ramazan Dikmen metinlerinin nezaket yüzüdür. Sanatçının, mektuplarındaki "Allah insanı gönüldaşsız bırakmasın", "Seninle konuşmak, dertleşmek, söyleşmek, saatlerce, günlerce, gecelerce...” ve "Dostluğu, bu kadim yangını son nefesimizle bile büyütmeliyiz." şeklindeki satırları, sanatçının birçok hayal kırıklıklarına, özleme, mahzuniyet uyandıran tecrübelerine karşın taşıdığı heyecanı korumakta kararlı olduğunu göstermektedir. 


\section{Modern Dünyanın Öğütücülüğüne İtiraz}

Modern dünyada çağdaş insanın açık bir bilinçle üzerinde durduğu temel açmazlardan biri, kendi, ailesi ve cemiyeti adına çağa karşı duyduğu aidiyet ikilemidir. Var olan bu bilinçli sorgulama biçimini, zahirde sadece ulusal ölçeğe indirgemek, meselenin ciddiyetine zarar verebilmektedir. Nitekim belirli bir medeniyet süzgecinden geçen, geleneksel öğretiler ve kabuller sahibi her millet, dünya genelinde yaşanmakta olan ölçüsüz dönüşümü sorgulayıc1, çeşitli kriz masaları oluşturabilir. "Zamanın ruhu"nu tayin eden gücün, önde gelen sermaye klikleri tarafindan mı yahut toplumun tüm tabakalarının dâhil olduğu, çoğulcu faydayı gözeten zümreler marifetiyle mi meydana geldiğini bilmek, söz konusu değişimin rengini de ele verebilmektedir.

Hikâyelerinin kapısını dönemin sosyal meselelerine sonuna kadar açan Ramazan Dikmen, insani değerlere dair özel bir hassasiyet taşımaktadır. Onun hikâyelerinde, eskiye saplanan bir üsluptan ziyade, ilkin memleketi, akabinde tüm insanlığ1 etkisi altına alma potansiyeli taşıyan modernizmin öğütücü yüzüne karşı getirilen eleştirel bir söylem bulunmaktadır. Metinlerinde toplum içinde infial uyandıracak hamlelerin farklı boyutlarıyla karşılaşmak mümkündür. Yazar, zamanın seküler ve büzüştürücü yapısından, cemiyetin kirli, şovenist ve çıkarcı yüzünden pür dikkat uzak durmaya çalışmakla kalmaz; disiplinli bir itiraz mekanizması geliştirerek geleneğin dört başı mamur erdemlilik şuurunu daima ön plana almaya gayret eder.

Yazarın eleştiri ve itiraz getirdiği ilk bahis, tekdüzeleşen mimari yapının yanında çevrenin üzerine zoraki giydirilen gri, beton örtülerdir. Kayıtlar'ın 1991 Ekim'inde yayımlanan "Geriye Kalan” hikâyesinde, seyir halinde yap1lan çevre tasviri olabildiğince doğal ilerlerken sarf edilen tek bir cümle, paragraftaki genel algının yön değiştirmesine etki eder: "Bir de antenli çatılarıyla $1 s s ı z$ köyler, beton yapılarıyla hep birbirine benzeyen şehirler" (s.37). "Sessiz Güvercinler"de de konaklama ve ikamet sistemindeki değişime muhalif bir tutum bulunur. Dikey yapılaşmanın ürkütücü boyutu bir yana, geçmiş zamanın aşina kıldığı mekânlar, yok olma tehlikesi altındadır: "Bir zamanlar dostlarıyla bahçesinde oturup sohbet etiği şirin kahvenin tümüyle yıkılarak yerine altı katlı devasa bir apartman dikileceğini de (tasavvur edemezdi)" (s.188). "Geçende" hikâyesi, eleştiri açısından doyurucu yargılar içerir. Önceki örnekteki gibi bu hikâyede Dikmen, anıları ve belleği içine hapseden vahamete dikkat çekmektedir. Nitekim toplumsal hayatta karşıllık bulan mekânlar, sadece fiziksel birer görünümden ibaret değil; aynı zamanda hatıra biriktiricisidir: 
"Hadi anılar durdurulamıyor. Alıp başını gidiyorlar, sisli, belli belirsiz bir yerlere. Bari onlara ait mekânlara ilişmeseler. Hepsini siliyorlar bir bir. Ne şirin bir kahveydi. Köşenin süsüydü. Serin köşe derdik oraya. Önünde narin söğütler vard. Bir teki kalmamış. Hepsini kesmişler” (s.81). Sermaye, gücünü yıkıp yeniden yapmakta bulur. Bu sirkülâsyona hayat veren etmenler ise, sınırlı dairede tam verim (kâr) sağlayacak imar alanlarıdır. Çoğu zaman "konformizm" sloganiyla hareket eden modern mimari, "süper", "mega" ve "hiper" benzeri sıfatlarla daima yükselen bir çizgide ve rekabet üzerinedir:

"Kiralık dükkanlar. Belki yeni bir süpermarket açarlar buraya. Hani tam da yeri. Kafası çalı̧ıyor adamların. Önceki iki katlı eski bir yapıydı. Onun yerine böyle büyükçe modern bir apartman yaptırmak çok daha kârlı bir iş. Dükkânlarınsa kahveden ne kadar fazla kazanacağı gün gibi ortada" (s.82). "Dar bir mekâna sıkıştııılmış olan insan, bunalım ve sıkıntıyı derinden hisseder. İnsanlığın bunaltı psikozuna dönüşmesi, modern toplumun temel problemlerinden biridir (Karabulut, 2011: 154).

Apartmanlaşma, beraberinde insanın daha dar bir alanda hayatını sürdürmesine zemin hazırlamakla kalmaz; çevrenin kendine has taşıdığı kimlik ve dokusunu da tahrip eder. Dikmen, klasik bir serzenişten ziyade eleştirisini, sistematik bir bütünlükte yürütmektedir. Yazar, aynı hikâyesinde çevre için doğal, estetik bir forma sahip ağaçlar ile yapı bakımından birbirine benzeyen, yapay ve tekrara düşen binalaşmayı mukayese eder. Betonlaşma, ciddi bir tehlike teşkil etmekte ve söz konusu dönüşüm olabildiğince bir hızla gerçekleşmektedir: "Binalarsa alıp başını gitmiş. Kat kat. Hepsi de çağdaş. Aralarında çekilmiş dişlerin yerleri gibi tek tük gedikler göze çarpıyor. Oralarda eski yapilardan hâlâ kalabilmiş. Çok geçmez. Onları da yıkarlar" (s.82). Modernite öncesi ve sonrası kıyas, metnin süresince devam eder. Türk kültür ve medeniyetine özgü ev (konak) sistemine duyulan bağllilk bir yana, Anadolu'nun karakteristik bütünlüğüyle özdeşleşen ahşap ve panjurlu her bir evin kaybı, aynı zamanda medeniyet bilincinin yok oluşuyla sonuçlanmaktadır: "Öncekiler. Sahi ne güzel evlerdi. Kutu gibi. İki katlı, sarı boyalı. Panjurlu pencereleri, çıtı pitı balkonları. Balkonlarda çiçek büyütülürdü. Evlerin arkaları bütün bahçeydi. Kirazlar, kayısılar ve ille de iğdeler olurdu bahçelerde. Artık o bahçeler de yok" (s.83). Tasvir edilen ev tipleri, bağımsız birer yaşam alanı olmasıyla beraber insana estetik meziyetler kazandırmasından ötürü, insanın kolektif bir bilinç taşımasına ve etrafindaki diğer canlı türlere karşı da sorumluluk sahibi olmasına, dolaylı yoldan ortam hazırlamaktadır.

"Geçende" hikâyesinde, konu bağlamındaki son örnek, modern insana ilişkindir. Öyle ki modern insan, iki zıt kutup arasında sıkışıp kalmış durumdadır. Mengenenin bir ucunu üretim çılgınlığı oluştururken, tüketim çılgınlığ1 
da diğer ucunu meydana getirir. Böylelikle modern insanın fikirsel ve ruhsal açıdan hareket etme kabiliyeti iyiden iyiye daralmaktadır:

"Hep üretmek, hep tüketmek. Sürekli üretimle sürekli tüketim arasında gerilip kalmı̧ minicik bir özneden öte ne ki günümüz insanı. Çă̆daş uygarlık vere vere bunu verebildi ona. Oysa daha yüce, daha anlamlı uğraşlar yaraşmaz mı insana" (s.85). "Arent'e göre iş toplumu olan modern toplum edim imkânını imha ederken, insanı 'animal laborans', yani çalışan hayvan derekesine indirmiştir. Modern insan edilgen olarak anonim hayat sürecinin insafına bırakılmıştır” (Chul Han 2018: 30).

İnsanın üretim sürecindeki etkisiz eleman konumu, tüketim sürecinde de devam eder. Esasen, performansa dayalı ve ölçüsüz rekabet ortamında üretici gibi görünen birey, kişiliğini, insani konumunu ve yaşamını bizzat kendi eliyle tükettiğinin de farkında değildir. Netice olarak bahsi geçen matematiksel denklemde rüştünü ispatlayan merci, yutan eleman kimliğiyle modernizmdir. "Sır"da, dönemin toplumsal ve ekonomik koşulları irdelenir. Maddi yetersizlikten dolayı çalışmak zorunda kalan aile fertlerinin, kızları Berna’yı gün içinde göstermeleri gereken ilgiden mahrum bırakmaları sonrasında aile büyükleri (anneanne önderliğinde), torunlarına sahip çıkar. Berna’nın, akrabaları tarafindan muhafaza edilmesindeki sebeplerden biri de aile efradı tarafindan benimsenemeyen kreş sistemidir. Üstelik bu sistemi makul görmeyen kişilerden biri de küçük kız çocuğunun kendisidir:

"Berna'ya biz bakıyoruz. Ablamla eniştem, ikisi de çalı̧ıyorlar. Gündüzleri evde ona bakacak kimse kalmıyor. Kreşe verseler o da ayrı dert. İlgilenmiyorlar çocuklarla. Üstelik çok pahalı. Hem baktık, Berna da istemiyor. Ne zaman kreş sözü açı1sa ağlayıp duruyor yavrucak. Annem sağolsun, bize verin biz bakalım Berna'ya dedi. Ablamlar da ses çıkarmadılar. Alıp getirdik. Çok da iyi oldu”(s.101).

Modern dünyanın çetin şartları, gitgide ebeveyni, birlikte çalışmaya zorlamaktadır. Bu durum, beraberinde aile bağlarının zedelenmesine sebebiyet vermektedir. Dikmen, "aile" kurumuna gösterdiği ihtimam sonucunda, kurtarıcıy1 yine aynı müessesede bulur; aile büyükleri. Fakat hikâyenin yayımlanma yılını göz önünde bulundurduğumuzda (Mavera, 1984), yazarın geleceğe dönük potansiyel sorunları dile getirdiğini, o tarihten günümüze toplumsal yönelimin Dikmen’in öngörüsü doğrultusunda gerçekleştiğini söylemek de mümkündür.

“Afife Abla’nın İncileri” hikâyesindeki ifadelerden yola çıkıldığında Afife Abla tiplemesi, imge üzerinden de okunabilir. Nitekim bu tiplemeyi, toplumsal duyarlılık, dayanışma, diğerkâmlık gibi etmenler meydana getirmektedir. 
Yazar, inanç değerlerinin ve insani değerlerin toplum gözünde peyderpey folklorik birer malzemeye indirgendiğini aktarırken metnin odağına ideal tiplemeyi koymaktan da geri durmaz. Herhangi bir kasabanın orta sınıfinda yaşanan gündelik hayatında dahi, yitmekte olan toplumsal duyarlılık, Afife benzeri tiplemelerle, modernizmin homojen ve ruhtan yoksun uygulamalarına mukavemet göstererek ayakta kalacaktır: "Eski günlerde olsa cenaze salası başladı mı mahallenin bütün gürültüsü bir anda kesilirdi. Herkes öleni öğrenmek için müezzinin ilanını beklerdi. Artık kimsenin böyle şeylere aldırdığ1 yok” (s.173). Ramazan Dikmen’in, modernizm karşısında unutulma tehlikesi yaşayan değer ve insan tiplerine yer verdiği hikâyelerinden bir diğeri de "Muhayyer"dir. Metinde geçen "Ne kadındı! Eski insanlara özgü, yaptığ1 her işe soylu bir zevk ve güzellik katma alışkanlığını bırakamıyordu” (s.26) cümlesi, gelenek-modernizm karşılaştırmasını mümkün kılarken bu tür kişiler, çağdaş dünyanın içine firlatılmış diğerkâm tipler şeklinde görünmektedir. Yazarın, vefatından bir yıl önce (1996) kaleme aldığı fakat bitiremediği, Ömer Lekesiz tarafindan tashih ve derlemesi yapılan "Gölgeler ve Kervan" adlı hikâye, Lekesiz' in ifadesiyle sanatçının ameliyat olan eşini konu edinir. Lekesiz, görünürde eşi için yazılan bu hikâyede, müellifin, bizzat tecrübe ettiğgi ameliyat sürecinin öncesine ve sonrasına dair çıkarımların bulunduğunu düşünmektedir (s.218). Ramazan Dikmen’in, hastane ve çalışanlarına ilişkin oldukça dikkatli gözlemlerde bulunduğu "Gölgeler ve Kervan”da, eleştirinin odağında bu kez modern tıp ve müntesipleri vardır. Nitekim ameliyathaneyi, mecazi bir tarifle "modern tıp dininin yeşil galoşlu, yeşil önlüklü, yeşil maskeli, yeşil boneli keşiş ve rahibelerinin teşrih ayini” (s.216) olarak tasavvur eden yazar, insanın, içinde bulunduğu acziyetle laboratuardaki denekten farksız olduğunu savunur. Doktor ve hemşirelere metin boyunca mesafeli ve temkinli yaklaşırken eleştiri dozajını artırdığı da olur. Dikmen'e göre hali hazırda aşırıya kaçan bir özgüven söz konusudur. Teknolojinin tanıdığı imkânla tıbbi donanımı elinde bulunduran modern birey, etrafındaki çoğu gelişmenin kontrolü altında olduğunu düşünmektedir: "Hatta seni bayıltan bayanın bonesiyle maskesi arasında sıkışmı̧ safra yeşili gözlerinde sırıtan anlamı artık tanımlayabiliyorsun: 'Elimizden gelmeyen yoktur. Ruhunu alır, sonra tekrar geri veririz!'”(s.218). Sonsuz gücü tekelinde barındırmak için muktedir kılındığına inanan çağdaş insan, "kendisinin maliği olduğu için, ona ne veya kim olması gerektiğini söyleyen bir üstü yoktur” (Chul Han 2018: 21). Homo Sapiens'in Homo Deus'a evrilişi muazzam bir hızla ilerlerken modern birey, eşref-i mahlûkat çizgisinden uzaklaşmaktadır. Bilimsel terakki, çevreyi korumak ve anlamlandırmak yerine tahakküm aygitı olarak görüldüğü sürece de çatışkı ve çıkmazlar kaçınılmaz olacaktır. 


\section{SONUÇ}

Kendi kabullerini edebi mecraya aktarmasindan dolayı Ramazan Dikmen hikâyelerini "tezli hikâye" sınıfında değerlendirmek mümkündür. Dikmen, inandığ 1 değerleri, oturmuş, karakteristik bir cümle düzeni içerisinde vermesinin yanı sıra geleneksel birikimin, zamanın kötücül ruhuna ne ölçüde itiraz edebileceğini sorgulamaktadır. Temel insani öğeleri ön plana almaya gayret eden yazar, ülkü ve karşıt değerleri çarpıştırarak birbirinden farklı kriz türlerinin (medeniyet, insani, inanç vb.) sebepleriyle birlikte akıbetini de tartışma ortamı olan metinlerine taşır. Geçmiş, Ramazan Dikmen nazarında "geçmemesi gereken" bir mevzudur. Bu tür bir 1srar, kabaca saplantı olarak görünmese de değişen dünya düzeninin "yutucu" bir tarafı olduğu açıktır. Bu sebeple çağdaş dünyada, insan ruhunu ehlileştiren musiki benzeri sanat dallarına, toplum içinde güven ve sadakati tesis eden kardeşlik ve dostluk hukukuna, etrafına model olacak ideal tiplere (şuurlu, erdemli, serdengeçti vb.) duyulan ihtiyaç çok daha fazla hissedilmektedir.

Muhayyer'deki çoğu hikâye, arayış üzerine temellenir. Yazar, adeta dertlenip sorguladığı hususlara iştirak edecek engin ruhların peşindedir. Kişilerin ekseriyeti özel bir isim taşımasa da naif birer kalp taşıdıkları söylenebilir. Kimi zaman iç sesini duymak temennisiyle kalabalıklardan kendini soyutlayan kişilerin bu tavrı ise egosantrik (benmerkezci) bir yalnılıktan öte uzleti andıran, teklikten çokluğa bir erişimdir. Müşterek ve kadim bilinç, Ramazan Dikmen hikâyelerinde daima ulvi bir noktadayken; süfli cephede modernite ve unsurları yer alır. 


\section{KAYNAKLAR}

Chul Han, Byung (2018). Yorgunluk Toplumu, Çev. Samet Yalçın, Açılım Kitap, İstanbul.

Dikmen, Ramazan (2015). Mubayyer, Hece Yayınları, Ankara.

Dikmen, Ramazan (2016). Tükenerek Çoğalmak, Hece Yayınları, Ankara.

Gemuhluoğlu, Fethi (2016). Dostluk Üzerine, İz Yayınc1lı, İstanbul.

Kaplan, Mehmet (2012). Nesillerin Ruhu, Dergâh Yayınları, İstanbul.

Lekesiz, Ömer (2017). Öykü Menzilleri-II, Şule Yayınları, İstanbul.

Teymur, Ahmet Selim (2010). Türk Musikisi, Pan Yayınc1lik, İstanbul.

Topçu, Nurettin (2019). Var Olmak, Dergâh Yayınları, İstanbul. 